\title{
High-Sensitivity C-Reactive Protein and Cardiovascular Disease
}

\author{
MK Mohsin, MU Ahmed \\ Department of cardiology, Square Hospitals Ltd., Dhaka.
}

(Cardiovasc. j. 2011; 3(2): 178-186)

About a half of all myocardial infarctions (MI) occur in individuals without overt hyperlipidemia. More than three quarters of all cardiovascular events occurs among those with low-density lipoprotein (LDL) cholesterol levels below $160 \mathrm{mg} / \mathrm{dL}$, and just less than half occurred among those with LDL cholesterol levels below $130 \mathrm{mg} / \mathrm{dL} .{ }^{1}$ About $20 \%$ of all coronary events occur in the absence of any major risk factor. ${ }^{2}$ In one recent analysis patients with CHD, $15 \%$ of the men and $19 \%$ of the women had no evidence of any major risk factor, and more than $50 \%$ had only 1 of these factors. ${ }^{3}$

In background of this some novel risk factors, including high sensitivity C-reactive protein (hsCRP), lipoprotein(a), homocysteine, fibrinogen, D-dimer, tissue plasminogen activator, and plasminogen activator inhibitor-1 antigen has attracted the attention in recent years. Among these hsCRP is the most promising biomarker in terms of clinical utility. ${ }^{4}$

hsCRP emerged as the most powerful single predictor of cardiovascular risk including CHD death, nonfatal MI, stroke, coronary revascularization \& outcome of peripheral arterial disease. ${ }^{5}$ Inflammation is characteristic in all phases of atherothrosclerosis and provides a link between early fatty streak formation up to plaque rupture leading to occlusion and infarction. ${ }^{6}$ Proinflammatory cytokines such as interleukin(IL-1) and tumor necrosis factor(TNF) potentiate the expression of adhesion molecules on vascular endothelial cells, leading to the recruitment of leucocytes to the arterial wall,. IL-1 \& TNF also activate chemokines that promote migration of monocytes into the subendothelial space. Mononuclear cells release growth factors that stimulate the proliferation of smooth muscle cells and lead to plaque progression. Mediators such as
CD40 ligand induce tissue factor expression and promote thrombus formation. Primary proinflammatory cytokines also stimulate the expression of interleukin-6, which create enhancement of inflammatory response, which leads to the production of CRP.

\section{What is CRP}

CRP is a member of the pentraxin family of innate immune response proteins (composed of $523-\mathrm{kd}$ subunits), synthesized by the liver in response to interleukin-6. Recent evidence suggests that CRP is also produced by smooth muscle cells of coronary arteries (particularly diseased vessels). ${ }^{7}$ It has been reported that levels of $\mathrm{CRP}$ in atherosclerotic plaque were 7 -and 10-fold higher than that in the liver and normal blood vessels. ${ }^{8}$ CRP influence vascular vulnerability (in vitro) by enhanced expression of endothelial cell surface adhesion molecules, ${ }^{9}$ monocyte chemoattractant protein-(1) endothelin ${ }^{10}$ and endothelial plasminogen activator inhibitor $^{11}$ reduced endothelial nitric oxide activity; ${ }^{10}$ and increased LDL uptake by macrophages ${ }^{12}$ Recent data also indicate that expression of human CRP enhances intravascular thrombosis in endothelial disruption. ${ }^{13}$

Serum hsCRP concentrations are lower than the tissue CRP concentrations (which promote atherogenic responses) Serum hsCRP levels less than $1 \mathrm{mg} / \mathrm{L}$ labeled as low, 1 to $3 \mathrm{mg} / \mathrm{L}$ labeled as intermediate, and greater than $3 \mathrm{mg} / \mathrm{L}$ labeled as high-risk. CRP at the cellular level usually ranges from 5 to $900 \mathrm{mg} / \mathrm{L}$ during inflammatory responses. On the other hand CRP concentrations as low as 5 $\mathrm{mg} / \mathrm{L}$ have been implicated to decrease nitric oxide production. ${ }^{10}$ One study suggests that low concentrations of hsCRP $(<0.5 \mathrm{mg} / \mathrm{L})$ are almost never associated with the future vascular event whereas concentrations greater than $10 \mathrm{mg} / \mathrm{L}$

Address of Correspondence: Dr. Md. Khaled Mohsin; Consultant, Cardiology, Square Hospitals Ltd., Dhaka, Bangladesh.email address: kmohsin@squarehospital.com. 
represent very high risk. ${ }^{14}$ Cut off value for clinically significant' circulatory level is $>1 \mathrm{mg} / \mathrm{L}$.

To reduce misclassification in clinical practice, hsCRP should be measured during acute stress, and both are recommended to be measured twice (preferably 2 weeks apart) because hsCRP levels have stability similar to that of LDLC on a monthto-month, year-to-year, and even decade-to-decade basis as has been observed in multiple prior studies. $^{15}$

\section{hsCRP and Cardiovascular Risk}

hsCRP predicts future cardiovascular risk in a wide variety of populations, including healthy individuals patients with acute coronary syndromes, stable angina, after MI, after percutaneous coronary intervention (PCI) and patients with the metabolic syndrome, diabetes, or renal disease.

hsCRP and Subclinical Atherosclerosis: Epidemiologic studies on general populations have found inconsistent associations between hsCRP and evidence of subclinical atherosclerosis such as carotid intimal-medial thickness (IMT) and coronary calcification as measured by electron beam computed tomography (EBCT). In a subset of Framingham Study, the top quartile of hsCRP was associated with relative risk (RR) of carotid stenosis (e"25\%) of 3.90 (95\% CI, 2.44-6.44) among women and 1.62 (95\% CI, 1.12-2.36) among men (16) . hsCRP level also correlated positively with the extent of coronary artery calcification in healthy participants evaluated with EBCT (73). Another study reported that persons with hsCRP level in the top tertile of the sample distribution were twice as likely to have moderate or severe carotid plaques than were persons in the bottom tertile (>2.77 vs <1.11 mg/L: RR, 2.0; 95\% CI, 1.3-3.0) after adjustment for BMI and other covariates (17). Autopsy studies have shown that elevated hsCRP is associated with increased macrophage density in atherosclerotic plaque, a higher prevalence of cap thinning, and increased risk of plaque erosions and rupture. ${ }^{18}$

In a 10-year follow-up study on elderly participants who had no history of stroke or atrial fibrillation at baseline, elevated hsCRP was predictive of ischemic stroke, independent of atherosclerosis severity. ${ }^{19}$ During follow-up of the same cohort, there was also a stronger relation between hsCRP and subsequent MI among individuals with evidence of subclinical disease than among those without such evidence. ${ }^{20}$

Acute coronary syndromes: A study reported that patients presenting with unstable angina and elevated plasma levels of hsCRP and serum amyloid A suffered higher adverse outcomes than did patients without the same, even in the absence of troponin elevation. ${ }^{21}$ TIMI investigators reported that the increased cardiac risk associated with high hsCRP levels may be evident as early as 14 days after presentation with an acute coronary syndrome. ${ }^{22}$ CAPTURE trial of abciximab in unstable angina poulations found that, hsCRP predicted risk of mortality or MI at 6 months ${ }^{23}$ and at 4 years. ${ }^{24}$ FRISC trial (on low-molecularweight heparin) reported the risk associated with elevated hsCRP levels at the time of the index event (unstable angina in $61 \%$ and $\mathrm{MI}$ in $39 \%$ of participants) continued to increase during a 3 -year follow-up. ${ }^{25}$

In the TIMI, CAPTURE, and FRISC studies, the predictive value of hsCRP was shown to be independent of, and additive to, troponin. An approach using hsCRP, troponin I, and B-type natriuretic peptide has been shown to improve risk prediction in patients with acute coronary syndromes. ${ }^{6}$ In patients of the TIMI trial (categorized on the basis of the number of elevated biomarkers at presentation), there was nearly doubled 30-day mortality risk for each additional biomarker elevation. Similar relations also existed for the endpoints of MI and congestive heart failure, and for the composite of the 3 outcomes, at 30 days and at 10 months.

Stroke: Recent reports suggest that hsCRP may be useful in predicting risk of subsequent cardiovascular events among persons with ischemic stroke. hsCRP levels were measured in ischemic stroke patients within 24 hours after onset. Compared with those in the bottom hsCRP quartile $(<5 \mathrm{mg} / \mathrm{L})$, individuals with an hsCRP level in the top quartile $(>33 \mathrm{mg} / \mathrm{L})$ and middle two quartiles (5-33 mg/L) had RRs of 4.04 and 1.37 respectively, of a future cardiovascular event in 2 years of follow-up. ${ }^{27}$

After percutaneous coronary intervention: It has been reported that hsCRP strongly predicted early 
complications (30-day risk of death or MI) after PCI in patients with a high percentage of use of stents and glycoprotein IIb/IIIa inhibitors; with the $\mathrm{RR}$ was 3.68 for the highest ( $>10 \mathrm{mg} / \mathrm{L}$ ) vs lowest $(<1.6 \mathrm{mg} / \mathrm{L})$ quartile comparison. The risk associated with elevated CRP was independent of, but additive to, the ACC/AHA lesion score. ${ }^{28}$ It was reported in a study (on patients of stable angina having received elective angioplasty) that hsCRP level ( $>3 \mathrm{mg} / \mathrm{L} \mathrm{vs}<3 \mathrm{mg} / \mathrm{L}$ ) was found to be a strong independent predictor of adverse coronary outcomes (death, MI, urgent revascularization, or admission for unstable angina) with a RR of 2.5. ${ }^{29}$ hsCRP was reported to be a better predictor than diabetes, hypertension, and ACC/AHA lesion class,. In another report, patients undergoing elective or urgent angioplasty were followed for up to 14 months.In multivariate analyses, elevated CRP level ( $>3 \mathrm{vs}<3 \mathrm{mg} / \mathrm{L}$ ) was an independent predictor of death or nonfatal MI (RR, 3.6) ${ }^{29}$ Nearly similar results came out of a 1-year follow-up of patients with stable angina who had undergone coronary stenting; Elevated. CRP levels ( $>5 \mathrm{vs}<5 \mathrm{mg} / \mathrm{L}$ ) were associated with a 1.8-fold increase in rate of death or MI but baseline hsCRP levels did not correlate with restenosis. ${ }^{30}$

Another follow up study of patients (who had undergone stenting of the culprit lesion) compared individuals with hsCRP levels of e" $10 \mathrm{mg} / \mathrm{L}$ with CRP levels d" $10 \mathrm{mg} / \mathrm{L}$. Higher CRP was implicated in RR of 4.2 for in-hospital death and a RR of 4.07 for death within 20 months. ${ }^{31}$

It was reported that preoperative elevated hsCRP $(>3 \mathrm{vs}<3 \mathrm{mg} / \mathrm{L})$ was associated with an increased risk of recurrent ischemia at 1 to 6 years after coronary artery bypass grafting ${ }^{32}$ hsCRP is also predictive of cardiovascular events in symptomatic patients of angiographically determined significant stenosis who are treated medically Absolute risk of death or MI found in patients with the lowest CAD scores (those with normal angiograms) and the highest hsCRP levels exceeded the risk for patients with highest CAD scores with the lowest hsCRP levels despite a higher prevalence of traditional coronary risk factors. ${ }^{33}$

Inflammation appears to be systemic rather than localized in patients with acute coronary syndromes but the precise source of CRP elevations remains unclear. ${ }^{34}$ It has been documented that hsCRP levels did not change after PTCA in patients with stable or unstable angina with normal preprocedural CRP levels but did increase after PTCA in patients with unstable angina and elevated hsCRP levels at baseline. ${ }^{35}$ Plaque rupture may not be the source of elevated hsCRP levels in unstable angina, but elevated hsCRP in this setting may be suggestive of hyperresponsiveness of the inflammatory system to smaller stimuli. As sirolimus and similar coatings present an antiproliferative, anti-inflammatory surface interface with the endothelium. These coated stents are likely to decrease event rates among individuals with elevated levels of hsCRP. hsCRP may be an important factor in the decision to use the drug eluting stents in certain patients, thereby potentially reducing the economic burden associated with widespread nonselective use of drug eluting stents. On the contrary if inflammatory activity is widespread and not limited to the lesion site drug eluting stents may not decrease future events.

Chronic phase after Myocardial Infarction: It has been reported in the CARE study that, patients with elevated hsCRP levels at 3 to 20 months after the MI were at higher risk of recurrent events during the 5-year follow-up period. ${ }^{36}$ Another study of patients with premature MI also found hsCRP to be a strong predictor of future cardiac death. The 10-year RR of cardiac mortality doubled with increasing CRP quartiles. Patients in the top quartile had 6 times the risk of cardiac death than did patients in the bottom quartile(adjusting age, left ventricular ejection fraction, serum cholesterol, fibrinogen, smoking, and hypertension). ${ }^{37}$ Another study found that, hsCRP levels measured 2 months after the index MI significantly predicted the risk of recurrent coronary events but the association lost the significant after adjustment for ejection fraction and presence of pulmonary oedema. ${ }^{38}$

In another study, hsCRP levels were measured in stable angina patients with or without exercise induced ischemia Individuals with levels of 3.8 $\mathrm{mg} / \mathrm{L}$ or above were far more likely to have exercise-induced ischemia ( $\mathrm{RR}, 4.2$; 95\% CI, 1.611.0). ${ }^{39}$ Thresholds used to define an abnormal or elevated CRP level among patients with documented coronary disease range from $3 \mathrm{mg} / \mathrm{L}$ 
to $5 \mathrm{mg} / \mathrm{L} \cdot{ }^{28,29}$ CAPTURE investigators found that a threshold of $10 \mathrm{mg} / \mathrm{L}$ maximized the predictive value of CRP in patients with unstable angina. ${ }^{23}$ Lowest distribution has been among healthy individuals, an intermediate range in stable $\mathrm{CAD}$, and the highest range in acute coronary syndromes. ${ }^{40}$

\section{Practical Considerations of hsCRP}

hsCRP Assays: Traditionally CRP has been used to monitor active infection \& inflmmmation related to musculoskeletal system. These assays are automated, reproducible, have a lower detection limit of 3 to $8 \mathrm{mg} / \mathrm{L}$ and is not sensitive enough to detect the lower levels for prediction of cardiovascular risk. To improve the sensitivity of $\mathrm{CRP}$ assays, the useful approach has been to amplify the light-scattering properties of the antigen-antibody complex by covalently coupling latex particles to a specific antibody. Most of the nearly 30 types of hsCRP assays, presently used employ this commercially available approach. ${ }^{41}$ Commonly used methods achieved sensitivities of less than or equal to $0.3 \mathrm{mg} / \mathrm{L}$ and had analytic variabilities of less than 10\% (reproducibility $>90 \%){ }^{42}$

Biologic Properties of CRP: hsCRP exhibits a relatively low range of variability in the same stable patients. In a study it was reported that, two separate measurements of hsCRP in the same individual 90 days apart classified of $90 \%$ of values in the same or immediately adjacent biomarker tertile. ${ }^{43}$ The CARE trial, reported moderate positive correlation $(\mathrm{r}=0.6)$ between two hsCRP measurements 5 years apart. ${ }^{44}$

If a value less than $10 \mathrm{mg} / \mathrm{L}$ is obtained, it is believed that a single hsCRP assessment is sufficient. The CDC and AHA recommend two hsCRP measurements taken 2 or more weeks apart, and the mean value is used to predict vascular risk. ${ }^{4}$ hsCRP levels may increase upto 100 -fold or more in response to acute infections or trauma, Levels above $10 \mathrm{mg} / \mathrm{L}$ should be ignored initially and the test repeated after stabilization. If elevation persists, then connective tissue disease, inflammatory bowel disease, or endocarditis should be excluded (particularly with elevated erythrocyte sedimentation rate). It has been reported, that individuals with persistent \& significant elevations of hsCRP appear to have exceptionally high coronary risk. ${ }^{14}$ In clinical studies, fewer than $2 \%$ of hsCRP values exceeds 15 $\mathrm{mg} / \mathrm{L}$, and persistent elevations are rare. $\mathrm{hsCRP}_{\mathrm{s}}$ levels are not influenced by food intake or circadian rhythm..$^{43}$ Owing to its pentraxin structure, hsCRP has a long plasma half-life (18 to 20 hours), Measurements can be made accurately from fresh or frozen blood (serum/plasma) without the need for special collection procedures. (41). CRP has been shown to be stable at $4^{\circ} \mathrm{C}$ for 60 days, ${ }^{45}$ at $70^{\circ} \mathrm{C}$ for longer than 20 years, ${ }^{46}$ and in liquid nitrogen for an indefinite period. ${ }^{47} \mathrm{hsCRP}$ levels have demonstrated specificity for vascular events and not predictive of cancer. ${ }^{48} \mathrm{~A}$ population-based cohort study of women ( $>65$ years) reported that an elevated CRP level strongly predicted cardiovascular mortality (CRP $>3 \mathrm{vs}<3 \mathrm{mg} / \mathrm{L}$ : adjusted RR, 8.0) but was unrelated to mortality from noncardiovascular causes. ${ }^{49}$

Population Distribution of hsCRP: Ranges of less than 1,1 to 3 , and greater $3 \mathrm{mg} / \mathrm{L}$, correspond to tertiles of the CRP distribution in healthy adults, which classifiy of individuals into low-, moderate-, and high-risk groups for primary cardiovascular prevention, ${ }^{4,50}$ Individuals with the lowest hsCRP levels $(<0.5 \mathrm{mg} / \mathrm{L})$ are at very low cardiovascular risk, whereas those with long-term marked elevations of hsCRP $(>10 \mathrm{mg} / \mathrm{L})$ are at very high risk. ${ }^{14}$

Genetic influence: Different studies suggest that CRP concentrations are in part genetically determined \& heritability of serum CRP level is approximately $40 \%$ to $50 \% .^{51}$

Sex: Circulating hsCRP concentrations, measured by high-sensitivity assays, appears comparable among men and women with the 50th percentile for both sexes being approximately $1.5 \mathrm{mg} / \mathrm{L} .{ }^{47}$ hsCRP levels are higher in women who use oral HRT which may be partly responsible for the increased risk of thrombotic events associated with oral HRT use. ${ }^{52}$ Selective estrogen receptor modulators do not raise hsCRP levels ${ }^{53}$ nor do transvaginal or transdermal estrogens. ${ }^{54}$

Age: Most studies report a modest relation between age and serum CRP concentrations. ${ }^{41,47}$ Reported median hsCRP concentrations for individuals aged 45 to 54,55 to 64,65 to 74 , and 75 years or older were $1.31,1.89,1.99$, and $1.52 \mathrm{mg} / \mathrm{L}$, respectively. ${ }^{41}$ 
Race/ethnicity. There was no reported significant differences in the distributions of hsCRP levels among European-American, African-American, Mexican-American men. and Japanese men. ${ }^{55}$ In contrast, hsCRP concentrations are reportedly higher in Mexican-American women than in European-American women. ${ }^{53}$ African-American women (compared to whites) had higher hsCRP levels and Asian-American women had lower level of hsCRP (compared to Hispanics). ${ }^{57}$

\section{Therapeutic Interventions}

It has not yet been conclusively proved that that lowering hsCRP levels leads to reduction in future cardiovascular events. many behavioral and pharmacologic interventions known to reduce the risk of clinical cardiovascular events have been linked to lower hsCRP levels. The goal of cardiovascular screening programs is the identification of high-risk individuals who can be targeted for weight loss, smoking cessation, increased physical activity, blood pressure control, and, where necessary, pharmacologic therapy. A patient's compliance with recommended interventions depends at least in part on his or her perception of absolute disease risk. Because the addition of hsCRP to lipid evaluation improves the prediction tool, hsCRP screening may be useful for this reason alone.

Pharmacologic Interventions: Several pharmacologic agents with demonstrated ability to reduce hsCRP levels.

1. Lipid-lowering agents: Lipid-modulating medications reported to affect hsCRP levels favorably include HMGCoA reductase inhibitors (statins), fibrates, and niacin. Statins are by far the most effective.

1.1. Statins: Cardiovascular benefits of statins extend beyond LDL cholesterol reduction. Benifits of statin therapy comes sooner than expected (even when LDL cholesterol has not started to reduce). Patients taking statins have a better prognosis than patients not taking the same even when LDL cholesterol levels are matched.Statins reduce ambulatory ischemia and symptomatic angina, events not generally explained by LDL reduction alone;. Statins also reduce risk of stroke although LDL cholesterol is not a major risk factor.,The CARE trial.first reported the hsCRP lowering ability of statins (pravastatin) because of its possible anti-inflammatory effects in addition of lipid-lowering. ${ }^{36,44}$ Confirmatory work showed that effect of statins on hsCRP was a consistent and important class effect. A meta-analytic review of the effects of statins on CRP, fibrinogen, homocysteine, oxidised LDL cholesterol, tissue plasminogen activator, plasminogen activator inhibitor, and platelet aggregation concluded that, among these, only hsCRP appears to be reduced by statins. ${ }^{58}$ All statins (pravastatin, lovastatin, cerivastatin, simvastatin, and atorvastatin) have shown to reduce median CRP levels by $15 \%$ to $25 \%$ as early as 6 weeks after initiation of therapy in different subsets of CAD patients. ${ }^{58,59}$ This reduction in CRP levels (and improving lipid profiles) is augmented by the addition of ezetimibe, (a cholesterol absorption inhibitor not affecting triglycerides and fat-soluble vitamins. ${ }^{60}$ Though ezetimibe alone had no reported effect on hsCRP. Magnitude of LDL cholesterol reduction due to statin therapy is minimally correlated with the magnitude of hsCRP reduction. ${ }^{58}$ It has been reported that the cardiovascular risk reduction attributable to statin therapy may be most marked in those having elevated hsCRP levels at baseline. In the CARE trial, recurrent events prevented by pravastatin was 54\% among persons with elevated hsCRP levels but only $25 \%$ among persons with lower hsCRP levels, though baseline lipid profile were nearly identical in both groups. ${ }^{44}$ In a primary prevention trial, lovastatin therapy was associated with a $42 \%$ reduction in first cardiovascular events among participants with LDL cholesterol levels $<149 \mathrm{mg} / \mathrm{dL}$ but hsCRP levels $>1.6 \mathrm{mg} / \mathrm{L} .{ }^{61}$ It has been reported that high hsCRP confers a dramatic increase in cardiovascular risk even in the absence of elevated LDL cholesterol. The randomized JUPITER trial investigating the effect of rosuvastatin vs. placebo on men and women with LDL cholesterol levels below $130 \mathrm{mg} / \mathrm{dL}$ but hsCRP levels above $2 \mathrm{mg} / \mathrm{L}$ in 4 year follow up to see the effect on first vascular events was stopped prematurely because of significant reduction in cardiovascular morbidity. ${ }^{71}$ The JUPITER trial also provided the proof of relative benefit of hsCRP reduction as compared with LDL cholesterol reduction. ${ }^{72}$

1.2. Fibrates: Small trials have shown that fibrates may also decrease plasma concentrations of hsCRP 
and other inflammatory markers in dyslipidemic patients ${ }^{62,63}$ CRP-lowering ability of fenofibrate $(200 \mathrm{mg} / \mathrm{d})$ was compared with that of atorvastatin $(10 \mathrm{mg} / \mathrm{d})$ and fenofibrate treatment was found to be more effective, ${ }^{64}$ In a double-blind trial fenofibrate and simvastatin $(20 \mathrm{mg} / \mathrm{d})$ found to be equally effective. ${ }^{64}$ Gemfibrozil, was shown to lower cardiovascular event rates without a significant reduction in LDL cholesterol. ${ }^{65}$

1.3. Niacin: It has been shown that combination of niacin and lovastatin ( $1000 \& 20$-mg respectively), reduced median hsCRP levels in dyslipidemic patients by $4 \%$ at 8 weeks and doubling the dose reduced hsCRP by $24 \%$ at one year $(\mathrm{P} \text {. .01 })^{66} \mathrm{In}$ another double-blind randomized trial on type 2 diabetic patients niacin (at doses of 1000 or 1500 $\mathrm{mg} / \mathrm{d}$,) reduced median hsCRP levels by $11 \%$, and $20 \%$ compared to placebo. ${ }^{67}$

2. Aspirin and other antiplatelet agents: A large primary prevention trial reported that the risk of future MI was reduced $56 \%$ by aspirin (325 $\mathrm{mg}$ on alternate days) in those with baseline CRP levels in the highest quartile and reduction was only $14 \%$ among those in the lowest quartile of CRP.This observation might suggest that aspirin may prevent ischemic events through antiinflammatory as well as antiplatelet effects. ${ }^{68}$ Published data indicate that the effects of clopidogrel and abciximab may be strongest in patients with elevated CRP levels before PCI. ${ }^{28,69}$ In contrast, ticlopidine conferred a significant reduction in subsequent cardiovascular events after ischemic stroke with admission hsCRP levels in the bottom 2 tertiles.. Nonsignificant excess risk was evident among those in the highest CRP tertile. ${ }^{27}$ Whether aspirin or other antiplatelet agents can lower CRP directly is uncertain. One trial found that six weeks of aspirin therapy (300 $\mathrm{mg} / \mathrm{d}$ ) significantly reduced CRP levels in patients with stable angina. ${ }^{70}$

\section{Clinical Recommendations}

Persons for whom National Cholesterol Education Program guidelines call for therapeutic intervention (based on serum LDL) an elevated hsCRP level should provide a strong impetus to improve compliance with diet and pharmacologic therapy. Whether or not patients with normal levels of LDL cholesterol but high levels of hsCRP will benefit from statin therapy as a primary prevention strategy has recently being tested in the JUPITER trial. CDC and the American Heart Association, recommends to measure hsCRP in individuals determined to be at intermediate cardiovascular risk on the basis of traditional risk factors. ${ }^{4}$

hsCRP predicts early and late mortality rates in acute coronary ischemia, adding to the prognostic value of cardiac troponin, and predicts outcomes after coronary stent placement. At present, apparently healthy individuals with elevated levels of hsCRP should be advised to lose excess weight, increase physical activity, stop smoking, and consult with their physicians concerning the use of aspirin and lipid-lowering therapies. In the future, novel anti-inflammatory therapies that directly target the vascular endothelium may become available.

\section{References:}

1. Ridker PM, Rifai N, Rose L, et al. Comparison of Creactive protein and low-density lipoprotein cholesterol levels in the prediction of first cardiovascular events. $N$ Engl J Med 2002; 347:1557-65.

2. Wilson PW, D'Agostino RB, Levy D, etal. Prediction of coronary heart disease using risk factor categories. Circulation 1998;97:1837-47.

3. Khot UN, Khot MB, Bajzer CT, et al. Prevalence of conventional risk factors in patients with coronary heart disease. JAMA 2003;290:898-904.

4. Pearson TA, Mensah GA, Alexander RW, et al. Markers of inflammation and cardiovascular disease: application to clinical and public health practice. A statement for healthcare professionals from the Centers for Disease Control and Prevention and the American Heart Association. Circulation 2003;107:499-511.

5. Ridker PM, Stampfer MJ, Rifai N. Novel risk factors for systemic atherosclerosis: a comparison of C-reactive protein, fibrinogen, homocysteine, lipoprotein(a), and standard cholesterol screening as predictors of peripheral arterial disease. JAMA 2001;285:2481-5.

6. Libby P, Ridker PM, Maseri A. Inflammation and atherosclerosis. Circulation 2002;105:1135-43.

7. Calabro P, Willerson JT, Yeh ET. Inflammatory cytokines stimulated C-reactive protein production by human coronary artery smooth muscle cells. Circulation 2003;108:1930-2.

8. Yasojima K, Schwab C, McGeer EG, McGeer PL. Generation of C-reactive protein and complement components in atherosclerotic plaques. Am J Pathol 2001;158:1039-51. 
9. Pasceri V, Willerson JT, Yeh ET. Direct proinflammatory effect of C-reactive protein on human endothelial cells. Circulation 2000;102:2165-8.

10. Verma S, Wang $\mathrm{CH}, \mathrm{Li} \mathrm{SH}$, et al. A self-fulfilling prophecy: C-reactive protein attenuates nitric oxide production and inhibits angiogenesis. Circulation 2002;106:913-9.

11. Devraj S, Xu DY, Jialal I. C-reactive protein increases plasminogen activator inhibitor-1 expression and activity in human aortic endothelial cells: Implications for the metabolic syndrome and atherothrombosis. Circulation 2003;107:398-404.

12. Zwaka Hombach V, Torzewski J. C-reactive proteinmediated low density lipoprotein uptake by macrophages: Implications for atherosclerosis. Circulation 2001;103:1194-7.

13. Danenberg HD, Szalai AJ, Swaminathan RV, et al. Increased thrombosis after arterial injury in human Creactive protein-transgenic mice. Circulation 2003;108:512-5.

14. Ridker PM, Cook NR. Clinical utility of very high and very low levels of C-reactive protein across the full range of Framingham risk scores. Circulation 2004;109: 1955-9.

15. Danesh Danesh J, Wheeler JG, Hirschfield GM, Eda S, Eiriksdottir G, Rumley A, Lowe GD, Pepys MB, Gudnason V. C-reactive protein and other circulating markers of inflammation in the prediction of coronary heart disease. N Engl J Med 2004;350:1387-1397.

16. Wang TJ, Nam BH, Wilson PW, et al. Association of Creactive protein with carotid atherosclerosis in men and women: the Framingham Heart Study. Arterioscler Thromb Vasc Biol 2002;22:1662-7.

17. van der Meer IM, de Maat MP, Bots ML, et al. Inflammatory mediators and cell adhesion molecules as indicators of severity of atherosclerosis: the RotterdamStudy. Arterioscler Thromb Vasc Biol 2002; 22:838-42.

18. Burke AP, Tracy RP, Kolodgie F, et al. Elevated Creactive protein values and atherosclerosis in sudden coronary death: association with different pathologies. Circulation 2002; 105:2019-23.

19. Cao JJ, Thach C, Manolio TA, et al. C-reactive protein, carotid intima-media thickness, and incidence of ischemic stroke in the elderly: the Cardiovascular Health Study. Circulation 2003; 108:166-70.

20. Tracy RP, Lemaitre RN, Psaty BM, et al. Relationship of C-reactive protein to risk of cardiovascular disease in the elderly. Results from the Cardiovascular Health Study and the Rural Health Promotion Project. Arterioscler Thromb Vasc Biol 1997; 17:1121-7.

21. Liuzzo G, Biasucci LM, Gallimore JR, et al. The prognostic value of C-reactive protein and serum amyloid A protein in severe unstable angina. $N$ Engl $J$ Med 1994; 331:417-24.
22. Morrow DA, Rifai N, Antman EM, Weiner DL, McCabe $\mathrm{CH}$, Cannon CP, and Braunwald E. C-reactive protein is a potent predictor of mortality independently of and in combination with troponin $\mathrm{T}$ in acute coronary syndromes: a TIMI 11A substudy. Thrombolysis in Myocardial Infarction. J Am Coll Cardiol 1998; 31:14601465.

23. Heeschen C, Hamm CW, Bruemmer J, Simoons M. Predictive value of $\mathrm{C}$-reactive protein and troponin $\mathrm{T}$ in patients with unstable angina: a comparative analysis. CAPTURE Investigators. Chimeric c7E3 AntiPlatelet Therapy in Unstable angina REfractory to standard treatment trial. J Am Coll Cardiol 2000; 35:1535-42.

24. Lenderink T, Boersma E, Heeschen C, et al. Elevated troponin $\mathrm{T}$ and $\mathrm{C}$-reactive protein predict impaired outcome for 4 years in patients with refractory unstable angina, and troponin $\mathrm{T}$ predicts benefit of treatment with abciximab in combination with PTCA. Eur Heart $J$ 2003;24:77-85.

25. Lindahl B, Toss H, Siegbahn A, Venge P, Wallentin L. Markers of myocardial damage and inflammation in relation to long-term mortality in unstable coronary artery disease. FRISC Study Group. Fragmin during Instability in Coronary Artery Disease. N Engl J Med 2000; 343:1139-47.

26. Sabatine MS, Morrow DA, de Lemos JA, et al. Multimarker approach to risk stratification in non-ST elevation acute coronary syndromes: simultaneous assessment of troponin I, C-reactive protein, and Btype natriuretic peptide. Circulation 2002;105:1760-3.

27. Di Napoli M, Papa F. Inflammation, hemostatic markers, and antithrombotic agents in relation to long-term risk of new cardiovascular events in first-ever ischemic stroke patients. Stroke 2002; 33:1763-71.

28. Chew DP, Bhatt DL, Robbins MA,et al. Incremental prognostic value of elevated baseline C-reactive protein among established markers of risk in percutaneous coronary intervention. Circulation 2001;104:992-997.

29. de Winter RJ, Heyde GS, Koch KT, et al. The prognostic value of pre-procedural plasma C-reactive protein in patients undergoing elective coronary angioplasty. Eur Heart J 2002;23:960-6.

30. Dibra A, Mehilli J, Braun S, et al. Association between C-reactive protein levels and subsequent cardiac events among patients with stable angina treated with coronary artery stenting. Am J Med 2003;114:715-22.

31. Muller C, Buettner HJ, Hodgson JM, et al. Inflammation and long-term mortality after non-ST elevation acute coronary syndrome treated with a very early invasive strategy in 1042 consecutive patients. Circulation 2002;105:1412-5.

32. Milazzo D, Biasucci LM, Luciani N, et al. Elevated levels of C-reactive protein before coronary artery bypass grafting predict recurrence of ischemic events. Am J Cardiol 1999;84:459-61. 
33. Zebrack JS, Muhlestein JB, Horne BD, Anderson JL. C-reactive protein and angiographic coronary artery disease: independent and additive predictors of risk in subjects with angina. J Am Coll Cardiol 2002;39:632-7.

34. Buffon A, Biasucci LM, Liuzzo G, D’Onofrio G, Crea F, Maseri A. Widespread coronary inflammation in unstable angina. $N$ Engl J Med 2002;347:5-12.

35. Liuzzo G, Buffon A, Biasucci LM, et al. Enhanced inflammatory response to coronary angioplasty in patients with severe unstable angina. Circulation 1998;98:2370-6.

36. Ridker PM, Rifai N, Pfeffer MA, et al. Inflammation, pravastatin, and the risk of coronary events after myocardial infarction in patients with average cholesterol levels. Cholesterol and Recurrent Events (CARE) Investigators. Circulation 1998;98:839-44.

37. Retterstol L, Eikvar L, Bohn M, et al. C-reactive protein predicts death in patients with previous premature myocardial infarction-a 10 year follow-up study. Atherosclerosis 2002;160:433-40.

38. Harb TS, Zareba W, Moss AJ, et al. Association of Creactive protein and serum amyloid $\mathrm{A}$ with recurrent coronary events in stable patients after healing of acute myocardial infarction. Am J Cardiol 2002;89:216-21.

39. Beattie MS, Shlipak MG, Liu H, Browner WS, Schiller $\mathrm{NB}$, Whooley MA. C-reactive protein and ischemia in users and nonusers of beta-blockers and statins: data from the Heart and Soul Study. Circulation 2003;107:245-50.

40. Bassuk SS, Rifai N, Ridker PM.High sensitivity Creactive protein:Clinical importance.Curr Problems in Cardiol.2004;29(9):439-93.

41. Ledue TB, Rifai N. Preanalytic and analytic sources of variations in C-reactive protein measurement: implications for cardiovascular disease risk assessment. Clin Chem 2003;49:1258-71.

42. Roberts WL, Moulton L, Law TC, et al. Evaluation of nine automated highsensitivity C-reactive protein methods: implications for clinical and epidemiological applications. Part 2. Clin Chem 2001;47:418-25.

43. Ockene IS, Matthews CE, Rifai N, Ridker PM, Reed G, Stanek E. Variability and classification accuracy of serial high-sensitivity C-reactive protein measurements in healthy adults. Clin Chem 2001;47:444-50.

44. Ridker et PM, Rifai N, Pfeffer MA, Sacks F, Braunwald E. Long-term effects of pravastatin on plasma concentration of C-reactive protein. The Cholesterol and Recurrent Events (CARE) Investigators. Circulation 1999; 100:230-5.

45. Kebler A, Grunert C, Wood WG. The limitations and usefulness of C-reactive protein and elastase-alpha 1proteinase inhibitor complexes as analytes in the diagnosis and follow-up of sepsis in newborns and adults. Eur J Clin Chem Clin Biochem 1994; 32:365-8.
46. Wilkins J, Gallimore JR, Moore EG, Pepys MB. Rapid automated high sensitivity enzyme immunoassay of Creactive protein. Clin Chem 1998;44:1358-61.

47. Rifai N, Ridker PM. Population distributions of Creactive protein in apparently healthy men and women in the United States: implication for clinical interpretation. Clin Chem 2003; 49:666-9.

48. Rifai N, Buring JE, Lee IM, Manson JE, Ridker PM. Is C-reactive protein specific for vascular disease in women? Ann Intern Med 2002; 136:529-33.

49. Tice JA, Browner W, Tracy RP, Cummings SR. The relation of C-reactive protein levels to total and cardiovascular mortality in older U.S. women. Am J Med 2003; 114:199-205.

50. Ridker PM. Clinical application of C-reactive protein for cardiovascular disease detection and prevention. Circulation 2003; 107:363-9.

51. MacGregor AJ, Gallimore JR, Spector TD, Pepys MB. Genetic effects on baseline values of C-reactive protein and serum amyloid A protein: a comparison of monozygotic and dizygotic twins. Clin Chem 2004; 50:130-4.

52. Manson JE, Hsia J, Johnson KC, et al. Estrogen plus progestin and the risk of coronary heart disease. $N$ Engl J Med 2003; 349:523-34.

53. Herrington DM, Brosnihan KB, Pusser BE, et al. Differential effects of estrogen and droloxifene on Creactive protein and other markers of inflammation in healthy postmenopausal women. J Clin Endocrinol Metab 2001;86:4216-22.

54. Vongpatanasin W, Tuncel M, Wang Z, Arbique D, Mehrad B, Jialal I. Differential effects of oral versus transdermal estrogen replacement therapy on Creactive protein in postmenopausal women. $\mathrm{J} \mathrm{Am} \mathrm{Coll}$ Cardiol 2003;41:1358-63..

55. Ford ES, Giles WH, Myers GL, Mannino DM. Population distribution of high-sensitivity C-reactive protein among US men: findings from National Health and Nutrition Examination Survey 1999-2000. Clin Chem 2003;49:686-690.

56. Ford ES, Giles WH, Mokdad AH, Myers GL. Distribution and correlates of C-reactive protein concentrations among adult US women. Clin Chem 2004;50:574-581.

57. Albert NA, Glynn RJ, Buring J, Ridker PM. C-reactive protein levels among women of various ethnic groups living in the United States (from the Women's Health Study). Am J Cardiol 2004;93:1238-42.

58. Balk EM, Lau J, Goudas LC, et al. Effects of statins on nonlipid serum markers associated with cardiovascular disease: a systematic review. Ann Intern Med 2003;139:670-82.

59. Kinlay S, Schwartz GG, Olsson AG, et al. High-dose atorvastatin enhances the decline in inflammatory markers in patients with acute coronary syndromes in the MIRACL study. Circulation 2003;108:1560-6. 
60. Ballantyne CM, Houri J, Notarbartolo A, et al. Effect of ezetimibe coadministered with atorvastatin in 628 patients with primary hypercholesterolemia: a prospective, randomized, double-blind trial. Circulation 2003;107:2409-15.

61. Ridker PM, Stampfer MJ, Rifai N. Novel risk factors for systemic atherosclerosis: a comparison of C-reactive protein, fibrinogen, homocysteine, lipoprotein(a), and standard cholesterol screening as predictors of peripheral arterial disease. JAMA 2001;285:2481-5.

62. Wang TD, Chen WJ, Lin JW, Cheng CC, Chen MF, Lee YT. Efficacy of fenofibrate and simvastatin on endothelial function and inflammatory markers in patients with combined hyperlipidemia: relations with baseline lipid profiles. Atherosclerosis 2003;170:315-23.

63. Despres JP, Lemieux I, Pascot A, et al. Gemfibrozil reduces plasma C-reactive protein levels in abdominally obese men with the atherogenic dyslipidemia of the metabolic syndrome. Arterioscler Thromb Vasc Biol 2003;23:702-3.

64. Melenovsky V, Malik J, Wichterle D, et al. Comparison of the effects of atorvastatin or fenofibrate on nonlipid biochemical risk factors and the LDL particle size in subjects with combined hyperlipidemia. Am Heart $J$ 2002;144:E6.

65. Rubins HB, Robins SJ, Collins D, et al. Gemfibrozil for the secondary prevention of coronary heart disease in men with low levels of high-density lipoprotein cholesterol. Veterans Affairs High-Density Lipoprotein Cholesterol Intervention Trial Study Group. $N$ Engl J Med 1999;341:410-8.

66. Kashyap ML, McGovern ME, Berra K, et al. Longterm safety and efficacy of a once-daily niacin/lovastatin formulation for patients with dyslipidemia. Am J Cardiol 2002;89:672-8.

67. Grundy SM, Vega GL, McGovern ME, et al. Efficacy, safety, and tolerability of once-daily niacin for the treatment of dyslipidemia associated with type 2 diabetes: results of the Assessment of Diabetes Control and Evaluation of the Efficacy of Niaspan Trial. Arch Intern Med 2002;162:1568-76.

68. Ridker PM, Cushman M, Stampfer MJ, Tracy RP, Hennekens $\mathrm{CH}$. Inflammation, aspirin, and the risk of cardiovascular disease in apparently healthy men. $N$ Engl J Med 1997;336:973-9.

69. Lincoff AM, Bittl JA, Kleiman NS et al REPLACE-1 Investigators. Comparison of bivalirudin versus heparin during percutaneous coronary intervention (the Randomized Evaluation of PCI Linking Angiomax to Reduced Clinical Events [REPLACE]-1 trial).Am $J$ Cardiol 2004;93:1092-1096.

70. Ikonomidis I, Andreotti F, Economou E, Stefanadis C, Toutouzas P, Nihoyannopoulos P. Increased proinflammatory cytokines in patients with chronic stable angina and their reduction by aspirin. Circulation 1999;100:793-8..

71. Ridker PM, Danielson E, Fonseca FAH, Genest J, Gotto $\mathrm{AM}$, et al .Rosuvastatin to prevent vascular events in men and women with elevated C-reactive protein. $N$ Eng J Med 2008; 359(21):2195-2207.

72. Ridker P M . The JUPITER Trial: Results, Controversies, and Implications for Prevention. Circ Cardiovasc Qual Outcomes 2009; 2: 279-285.

73. Wang TJ, Larson MG, Levy D, et al. C-reactive protein is associated with subclinical epicardial coronary calcification in men and women: the Framingham Heart Study. Circulation 2002;106:1189-91. 